\title{
Bransonelliformes - a new order of the Xenacanthimorpha (Chondrichthyes, Elasmobranchii)
}

\author{
Oliver Hampe ${ }^{*, 1}$ and Alexander Ivanov ${ }^{* *, 2}$ \\ ${ }^{1}$ Museum für Naturkunde der Humboldt-Universität zu Berlin, Invalidenstraße 43, D-10115 Berlin, Germany \\ 2 Department of Palaeontology, St. Petersburg University, 16 Linija 29, St. Petersburg 199178, Russia
}

Received 18 December 2006, accepted 21 February 2007

Published 1 August 2007

With 2 figures, 1 table

Key words: Xenacanthimorpha, Bransonella, Barbclabornia, phylogeny.

\begin{abstract}
The order Bransonelliformes is erected for the genera Bransonella Harlton, 1933 and Barbclabornia Johnson, 2003 based on the distinct characters of an inverted "V"-nested pattern of ornamentation preliminary on the labial aspect at the tooth cusps, the presence of labial foramina, and the occasional occurrence of a centrally positioned lingual opening of a main nutrient canal at the bases of the teeth. The Bransonelliformes comprises the primitive sister group to the Xenacanthiformes within the Xenacanthimorpha.
\end{abstract}

Schlüsselwörter: Xenacanthimorpha, Bransonella, Barbclabornia, Phylogenie.

\section{Zusammenfassung}

Für die Gattungen Bransonella Harlton, 1933 und Barbclabornia Johnson, 2003 wird die neue Ordnung Bransonelliformes eingeführt basierend auf den Merkmalen von bevorzugt auf der labialen Seite der Zahnspitzen auftretenden, dachziegelartig ineinander geschachtelten Skulpturleisten, dem Vorhandensein labialer Foramina sowie dem häufigen Auftreten einer größeren lingualen Öffnung an der Zahnbasis, dem Durchtritt eines zentralen Nährkanals. Die Bransonelliformes stellen die ursprünglichere Schwestergruppe zu den Xenacanthiformes innerhalb der Xenacanthimorpha dar.

\section{Updated knowledge}

Bransonella is an elasmobranch genus known only from teeth. It has a tricuspid crown and a lingually extended base with a coronal button on the upper side and a basal tubercle situated on the bottom side as is typical for xenacanthiform teeth. Three species are recognized to date: the early Pennsylvanian B. tridentata from Oklahoma (Harlton 1933, first identified as a conodont), B. nebraskensis from late Pennsylvanian deposits of Nebraska (Johnson 1984, as Xenacanthus? nebraskensis) and Kansas
(Tway \& Zidek 1983, as "Subtype 173" in an ichthyolith catalogue) and from early Permian strata of Kansas (Schultze 1985, as Xenacanthus luedersensis), and B. lingulata from Viséan deposits of the Kuznetsk Basin (Rodina \& Ivanov 2002) and Serpukhovian rocks of the Moscow syneclise (Ivanov \& Ginter 1996). B. nebraskensis was identified also from Viséan sediments of the Nearpolar and South Urals (Ivanov \& Ginter 1996), the Kuznetsk Basin (Rodina \& Ivanov 2002) in Russia, the Holy Cross Mountains in Poland (Ivanov \& Ginter 1996), and from the Dinant synclinorium in Belgium (Derycke

\footnotetext{
* Corresponding author: e-mail: oliver.hampe@museum.hu-berlin.de

** E-mail: elasmo2004@yandex.ru
} 


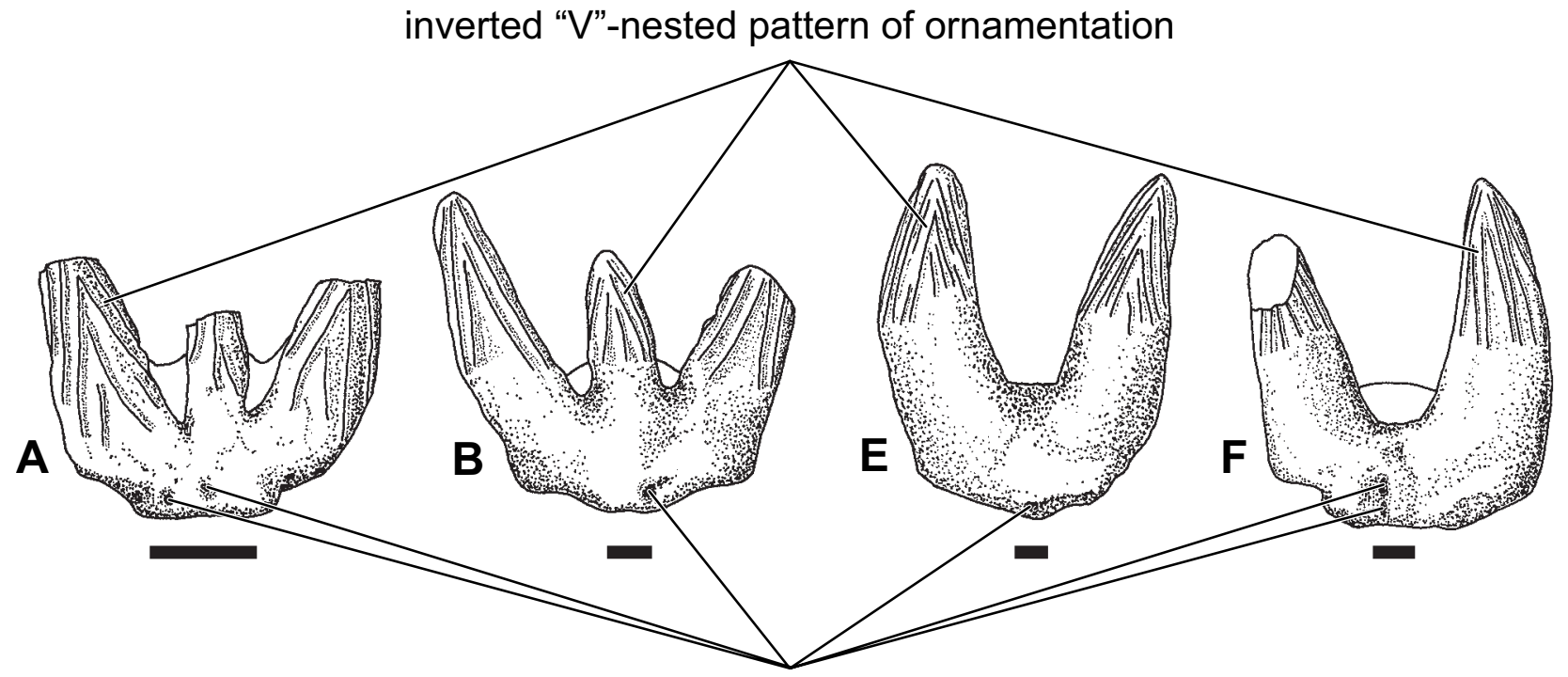

labial foramina

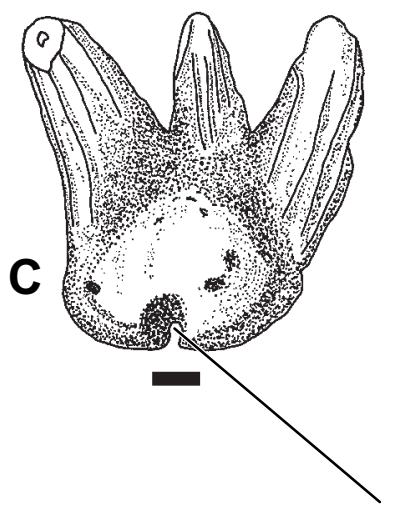

lingual notch
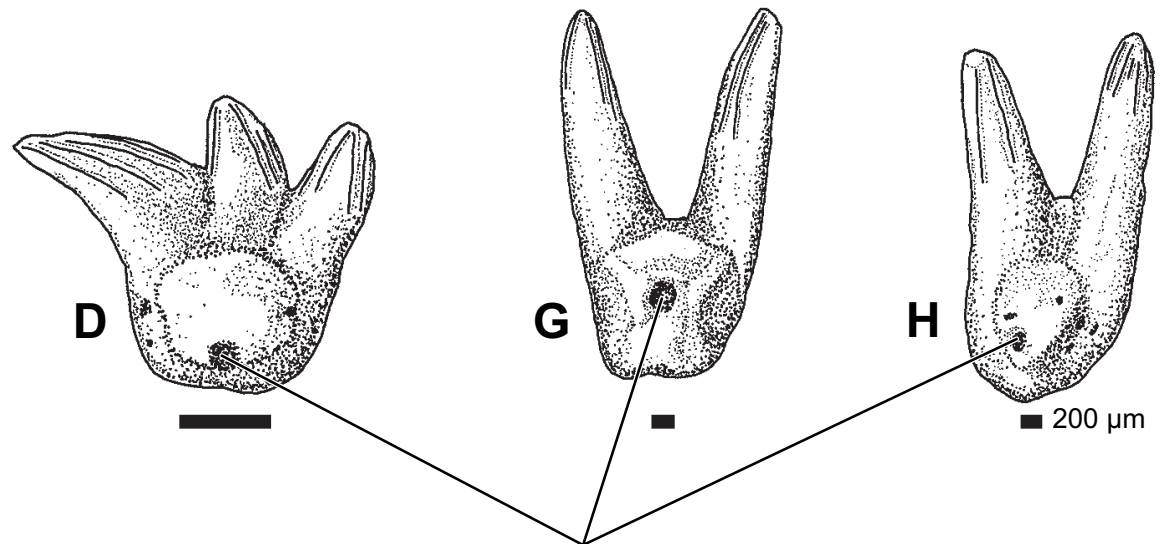

central opening of main nutrient canal

Fig. 1. Typical teeth of Bransonella (A-D) and Barbclabornia $(\mathbf{E}-\mathbf{H})$ and their characteristic features. A - Bransonella lingulata, LP 16-3, from Kalinovskie Vyselki Quarry, Moscow Syneclise, Russia (Serpukhovian, late Mississippian), in labial view; B - Bransonella nebraskensis, TMM 41648-139, in labial view; C - Bransonella nebraskensis, TMM 41647-20, in lingual view, both from Nemaha County, Nebraska, USA (Virgilian = Gzhelian, late Pennsylvanian); D - Bransonella nebraskensis, LP 162, from Kozhim River, Polar Urals, Russia (Visean, Mississippian), in lingual view; E - Barbclabornia luedersensis, SMU 64112, from Wolf Creek, Texas, USA (Artinskian, Cisuralian), in labial view; F - Barbclabornia luedersensis, SMNS 52067.1, from Jefferson County, Oklahoma, USA (Wolfcampian, Cisuralian), in labial view; G - Barbclabornia luedersensis, SMU 64101, from Spring Creek, Texas, USA (Artinskian, Cisuralian), in lingual view; H - Barbclabornia luedersensis, SMU 64056, from West Franklin Bend, Texas, USA (Artinskian, Cisuralian), in lingual view. Drawings based on figures from Ivanov \& Ginter (1996: A, D), Johnson (1984; B, C; 2003: E, G, H) or are from the first author (F). Abbreviations: LP (Laboratory of Palaeontology, St. Petersburg University, Russia); SMNS (Staatliches Museum für Naturkunde, Stuttgart, Germany); SMU (Southern Methodist University, Dallas, Texas); TMM (Texas Memorial Museum, University of Texas, Austin).

et al. 2005), as well as from Moscovian deposits of the Moscow syneclise, Russia (Lebedev 2001). Additional teeth and tooth fragments certainly belonging to Bransonella are reported from Mississippian sediments of North Qilian Mountain in China (Wang et al. 2004), from Pennsylvanian deposits of the Amazon Basin in Brazil (Duffin et al. 1996, as ?Triodus sp.) and of the Bükk Mountains in Hungary (Kozur 1984, as Xenacanthus sp.).

The resemblance to Bransonella, due to poor or corroded preservation, is questionable in remains described by Ji \& Ziegler (1992) from Guilin, South China (late Famennian), Xia (1997) from Xinjiang,
North China (middle Famennian), Ivanov (1999) from Timan-Pechora Province, Russia (early Tournaisian), Ginter (2001) from Utah, USA (late Famennian), and Ginter et al. (2002) from Dalmeh, Iran (late Famennian). Some of these may belong to the Jalodontidae (phoebodontiform sharks, known by teeth having an ornament of the cusps similar to that of Bransonella, but with a different morphology of the base; Ginter et al. 2002), while others might be an early form of Bransonella.

Species of Bransonella share some peculiar characters that never occur in sharks of the order Xenacanthiformes. These are the inverted "V"-nested 
cusp ornamentation reaching the base, the presence of labially positioned foramina on the base, and the lingual position of a large central opening of a main nutrient canal forming often a distinct notch at the lingual margin of the base.

The general tricuspid tooth morphology is the reason why Bransonella was often identified as a xenacanthid in the past. Chronologially, Zidek (1973) identified B. tridentata as belonging to the genus Dittodus. Zangerl (1981) grouped Bransonella under Xenacanthidae incertae sedis. Johnson (1984) assigned the Nebraskan teeth to the genus Xenacanthus, but pointed out similarities to B. tridentata. Zidek (1993) then characterised Bransonella as a true xenacanthiform. Schneider (1996) groups the 'crushing-type' teeth in the family Xenacanthidae. Ginter \& Ivanov (1996) see in Bransonella a representative of the Xenacanthida. Ivanov \& Ginter (1996) also followed this position and classify Bransonella as to be a xenacanthid belonging to the order Xenacanthida and Family indet. However, they mentioned that the characteristic ornamentation of Bransonella does not occur in any other representative of the Xenacanthida/Xenacanthiformes [Berg (1940) established the subclass Xenacanthi and order Xenacanthiformes. Glikman (1964) was the first author who suggested superordinal rank for the "Xenacanthi" and used dental characters to define the superorder and the order "Xenacanthida". The definition of Berg, however, has priority, even though he used no dental features in his diagnoses.]. Ginter et al. (2002) attributed Bransonella to Xenacanthiformes and Family indet. as did Wang et al. (2004: Xenacanthida and Family indet.). Hampe (2003) indicated that further information and investigation is needed to resolve the position of Bransonella. Subsequently, Hampe et al. (2004) demonstrated a sister group relationship with the Xenacanthidae. Bransonella is defined in their analysis by the presence of an inverted "V"-nested pattern of the cusps and a large central opening of a main nutrient canal at the lingual margin of the base. Characters shared with representatives of the xenacanthids are regarded as parallel developments. Hampe et al. (2004) assume that Bransonella and xenacanthids probably shared the same ancestor, perhaps a phoebodont. Also Ginter (2004) discussed the possibility of a transition from a phoebodont (ancestor) to the xenacanth dentition, probably via Bransonella and/or Jalodus, a widespread tooth genus from the Late Devonian (middle Fammenian) to Tournaisian, which has a tricuspid crown of very strong cusps and the same ornamentation as Bransonella.

Another problematic taxon is the newly erected genus Barbclabornia (Johnson 2003), based on a species described first by Berman (1970: Xenacanthus luedersensis). The usually bicuspid teeth of Barbclabornia luedersensis are known from Late Carboniferous(?) and Early Permian sediments of Texas and Oklahoma also show, like teeth of Bransonella, an inverted "V"-nested pattern of ornamentation, here covering the upper half of the cusps concentrated on the labial aspect. Also labial foramina can be present at the base. A centrally positioned canal opening can be situated at the lingual margin of the base or on the surface of the coronal button (first author, pers. observ.). The teeth belong to an elasmobranch of estimated 4.5 to $5 \mathrm{~m}$ in total length based on the data of a preserved palatoquadrate (see Zidek et al. 2003). Combined with the small teeth (average of $2 \mathrm{~mm}$ height) Zidek

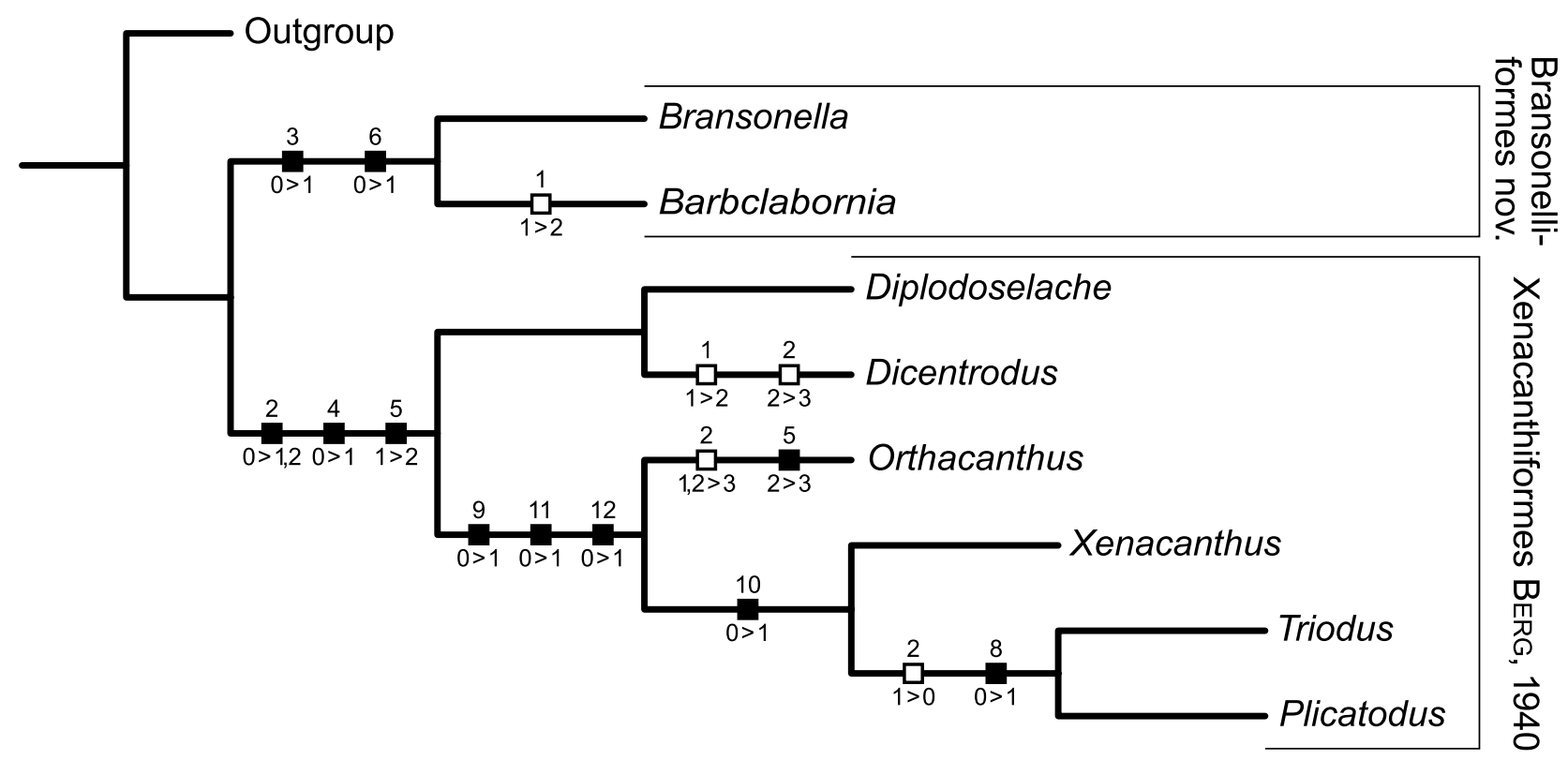

Fig. 2. Phylogenetic analysis of the Xenacanthimorpha with unambiguous character changes [heuristic search setting; tree length $=24$; consistency index $(\mathrm{CI})=0.790$; retention index $(\mathrm{RI})=0.780$ ]. The character numbers are placed above the squares, the character states below. 
Table 1

Character matrix

\begin{tabular}{|c|c|c|c|c|c|c|c|c|c|c|c|c|c|}
\hline Character \# & 1 & 2 & 3 & 4 & 5 & 6 & 7 & 8 & 9 & 10 & 11 & 12 & 13 \\
\hline Outgroup & 0 & 0 & 0 & 0 & 0 & 0 & 0 & 0 & 0 & 0 & 0 & 0 & 0 \\
\hline Diplodoselache & 1 & 2 & 0 & 1 & 2 & 0 & 1 & 0 & 0 & 0 & 0 & 0 & 0 \\
\hline Dicentrodus & 2 & 3 & 0 & 1 & 2 & 0 & 1 & 0 & 0 & 0 & 0 & $?$ & $?$ \\
\hline Orthacanthus & 1 & 3 & 0 & 1 & 3 & 0 & 2 & 0 & 1 & 0 & 1 & 1 & $?$ \\
\hline Xenacanthus & 1 & 1 & 0 & 1 & 2 & 0 & $1 \& 2$ & 0 & 1 & 1 & 1 & 1 & 1 \\
\hline Triodus & 1 & 0 & 0 & 1 & 2 & 0 & 2 & 1 & 1 & 1 & 1 & 1 & 1 \\
\hline Plicatodus & 1 & 0 & 0 & 1 & 2 & 0 & 2 & 1 & 1 & 1 & 1 & $?$ & $?$ \\
\hline Bransonella & 1 & 0 & 1 & 0 & 1 & 1 & 2 & 0 & $?$ & $?$ & $?$ & $?$ & $?$ \\
\hline Barbclabornia & 2 & 0 & 1 & 0 & $1 \& 2$ & 1 & 2 & 0 & $?$ & $?$ & $?$ & $?$ & $?$ \\
\hline
\end{tabular}

et al. (2003: 143) assume that Barbclabornia luedersensis was a large filter feeder like the extant basking shark or whale shark.

\section{A new systematic status}

Based on the striking differences in tooth morphology (ornamentation of cusps, presence of labial foramina and a frequently occurring lingual nutrient canal opening), which do not correspond with those known from representatives of other xenacanthiforms, we propose the exclusion of Bransonella and Barbclabornia from the order Xenacanthiformes/Xenacanthida. A cladistic analysis of different xenacanthimorph genera based on the characters listed below confirms our suggestion (Fig. 2). A single tree resulted placing Bransonella and Barbclabornia as the most basal taxa in the analysis. The cladistc analysis was performed using the programs WINCLADA (Nixon 2002) and NONA (Goloboff 1999).

Character list:

[1] Teeth multicuspid (0), tricuspid (1), bicuspid (2)

[2] Cusps without lateral cutting edges (0), cusps lanceolate with always smooth lateral edges (1), edges muricated (2), edges serrated (3)

[3] Simple or no vertical cristae at the cusps (0), ornamentation of inverted "V"-nested pattern (1)

[4] Tooth base with labially positioned nutrient foramina (0), lack of labial foramina (1)

[5] No basal tubercle developed on the bottom side of the base (0), bottom side of base with a prominent developed, halfmoon-shaped basal tubercle (1), closed and rounded with concave depression (2), rounded without depression (3)

[6] General absence of a central canal opening at the lingual margin of the base (0), presence of a central canal opening common (1)

[7] Crown of teeth (cusps) consisted of trabecular dentine (0), cusp with only basal cone-like trabecular dentine core - remaining tissue orthodentine (1), exclusively orthodentine (2)

[8] Base of teeth consists of trabecular dentine (0), base consists of orthodentine (1)
[9] Dorsal spine not cranial (0), dorsal spine cranial (1)

[10] Dorsal spine with rounded cross-section and ventrad arranged double-row of denticles (0), spine dorso-ventrally compressed with clearly lateral positioned rows of denticles (1)

[11] Dorsal spine with irregular, bark-like surface structure (0), relatively smooth surface including delicate striations (1)

[12] Pectoral fins not of archipterygium type (0), biserial archipterygium (1)

[13] Caudal fin heterocercal (0), caudal fin diphycercal (1)

We propose a systematic position for Bransonella and Barbclabornia within the superorder Xenacanthimorpha and erect a new order, Bransonelliformes n. ord., for these distinct genera.

Superorder Xenacanthimorpha Berg, 1940 Order Bransonelliformes n. ord.

Diagnosis. Xenacanthimorph teeth with an inverted "V"-nested pattern of ornamentation, the presence of labial foramina, and the frequent occurrence of a large central opening of a main nutrient canal at the base.

Included genera. Bransonella Harlton, 1933; Barbclabornia Johnson, 2003

\section{Conclusion}

The systematic situation of the genera Bransonella Harlton, 1933 and Barbclabornia Johnson, 2003, often labelled as xenacanthiform sharks (by, among others, Zangerl 1981; Schneider 1996; Ginter et al. 2002) is revised. A recent cladistic analysis of the Xenacanthimorpha confirmed the separation of Bransonella (including the recently erected Barbclabornia) from the order of Xenacanthiformes Berg, 1940 (= Xenacanthida Glikman, 1964) as suggested by Hampe et al. (2004).

\section{Acknowledgements}

We thank Elke Siebert (Berlin), who drew the cladogram. We also would like to express out thanks to Rodrigo Soler- 
Gijón (Berlin, Madrid) for helpful discussions. Linda Tsuji (Berlin) kindly improved the English text. Sincere thanks are going also to Chris J. Duffin (London), Michał Ginter (Warsaw), and an anonymous referee who acted as reviewers and provided valuable comments.

\section{References}

Berg, L. S. 1940. Sistema ryboobraznykh i ryb, nyne zhivushchikh i ickopaemykh. - Trudy Zoologicheckogo instituta Akademii nauk SSSR 5 (2): 87-345.

Berman, D. S. 1970. Vertebrate fossils from the Lueders Formation, Lower Permian of north-central Texas. - University of California Publications, Geological Sciences 86: $1-39$.

Derycke, C., Ivanov, A. \& Weber, H. M. 2005. Late Viséan vertebrate assemblage from Belgium. - Ichthyolith Issues, Special Publication 8: 7-8.

Duffin, C. J., Richter, M. \& Neis, P. A. 1996. Shark remains from the Late Carboniferous of the Amazon Basin, Brazil. - Neues Jahrbuch für Geologie und Paläontologie Monatshefte 1996 (4): 232-256.

Ginter, M. 2001. Chondrichthyan biofacies in the late Famennian of Utah and Nevada. - Journal of Vertebrate Paleontology 21 (4): 714-729.

- 2004. Devonian sharks and the origin of Xenacanthiformes. - In Arratia, G., Wilson, M. V. H. \& Cloutier, R. (eds). Recent advances in the origin and early radiation of vertebrates honoring Hans-Peter Schultze: 473-486, Pfeil, München.

Ginter, M. \& Ivanov, A. 1996. Relationships of Phoebodus. Modern Geology 20: 263-274.

Ginter, M., Hairapetian, V. \& Klug, C. 2002. Famennian chondrichthyans from the shelves of North Gondwana. Acta Geologica Polonica 52 (2): 169-215.

Glikman, L. S. 1964. Klass Chondrichthyes, Podklass Elasmobranchii. - In Orlov, Yu. A. (ed.). Osnovy Paleontologii, 11. Agnathes, Pisces: 195-236. Nauka, Moskva.

Goloboff, P. 1999. NONA (NO NAME) ver. 2. - published by the author, Tucumán, Argentina.

Hampe, O. 2003. Revision of the Xenacanthida (Chondrichthyes: Elasmobranchii) from the Carboniferous of the British Isles. - Transactions of the Royal Society of Edinburgh: Earth Sciences 93 (3): 191-237.

Hampe, O., Aboussalam, Z. S. \& Becker, R. T. 2004. Omalodus teeth (Elasmobranchii: Omalodontida) from the northern Gondwana margin (middle Givetian: ansatus conodont Zone, Morocco). - In Arratia, G., Wilson, M. V. H. \& Cloutier, R. (eds). Recent advances in the origin and early radiation of vertebrates honoring Hans-Peter Schultze: 487-504, Pfeil, München.

Harlton, B. H. 1933. Micropaleontology of the Pennsylvanian Johns Valley shale of the Ouachita Mountains, Oklahoma, and its relationship to the Mississippian Caney shale. Journal of Paleontology 7 (1): 3-29.

Ivanov, A. 1999. Late Devonian - Early Permian chondrichthyans of the Russian Arctic. - Acta Geologica Polonica 49 (3): $267-285$.

Ivanov, A. \& Ginter, M. 1996. Early Carboniferous xenacanthids (chondrichthyes) from eastern Europe. - Bulletin de la Société géologique de France 167 (5): 651-656.
Ji Qiang \& Ziegler, W. 1992. Introduction to some Late Devonian sequences in the Guilin area of Guangxi, South China. - Courier Forschungsinstitut Senckenberg 154: 149-177.

Johnson, G. D. 1984. A new species of Xenacanthodii (Chondrichthyes, Elasmobranchii) from the late Pennsylvanian of Nebraska. - In Mengel, R. M. (ed.). Papers in Vertebrate Paleontology honoring Robert Warren Wilson. Carnegie Museum of Natural History, Special Publication 9: $178-186$.

- 2003. Dentitions of Barbclabornia (new genus, Chondrichthyes: Xenacanthiformes) from the Upper Palaeozoic of North America. - Mitteilungen aus dem Museum für Naturkunde in Berlin, Geowissenschaftliche Reihe 6: 125-146.

Kozur, H. 1984. Biostratigraphic evaluation of the Upper Paleozoic conodonts, ostracods and holothurian sclerites of the Bükk Mts. Part I: Carboniferous conodonts and holothurian sclerites. - Acta Geologica Hungarica 27 $(1-2): 143-162$

Lebedev, O. A. 2001. Vertebrates. - In Alekseev, A. S. \& Shik S. M. (eds). Middle Carboniferous of Moscow Syneclise (Southern Part), Volume 2: Paleontology: 92-104, Nauchniy Mir, Moskva.

Nixon, K. C. 2002. WinClada ver. 1.00.08. - published by the author, Ithaca, New York.

Rodina, O. A. \& Ivanov, A. O. 2002. Chondrichthyans from the Lower Carboniferous of Kuznetsk Basin. - In Chuvashov, B. I. (ed.). Stratigrafiya i Paleogeografiya Karbona Evrazii: 263-268, Ekaterinburg.

Schneider, J. W. 1996. Xenacanth teeth - A key for taxonomy and biostratigraphy. - Modern Geology 20: 321-340.

Schultze, H.-P. 1985. Marine to onshore vertebrates in the Lower Permian of Kansas and their paleoenvironmental implications. - University of Kansas Paleontological Contributions 113: $1-18$

Tway, L. E. \& Zidek, J. 1983. Catalog of late Pennsylvanian ichthyoliths, Part II. - Journal of Vertebrate Paleontology 2 (4): 414-438.

Wang Nian-Zhong, Jin Fan \& Wang Wie 2004. Early Carboniferous fishes (Acanthodian, Actinopterygians and Chondrichthyes) from the east sector of North Qilian Mountain, China - Carboniferous fish sequence from the from the east sector of North Qilian Mountain (1). - Vertebrate Palasiatica 42 (2): 89-110.

Xia Feng-Sheng 1997. Marine microfaunas (bryozoans, conodonts and microvertebrate remains) from the FrasnianFamennian interval in Northwestern Junggar Basin of Xinjiang in China. - Beiträge zur Paläontologie 22: 97-207.

Zangerl, R. 1981. Chondrichthyes I - Paleozoic Elasmobranchii. - In Schultze, H.-P. (ed.). Handbook of Paleoichthyology 3A: 115 pp., Fischer, Stuttgart.

Zidek, J. 1973. Oklahoma Paleoichthyology Part II: Elasmobranchii (Cladodus, minute elements of Cladoselachian derivation, Dittodus, and Petrodus). - Oklahoma Geological Notes 33 (3): 87-103.

- 1993. Xenacanthid genera: How many and how to tell them apart? - In Heidtke, U. (ed.). New Research on Permo-Carboniferous Faunas. - POLLICHIA-Buch 29: $23-35$.

Zidek, J., Johnson, G. D., May, W. \& Claborn, A. 2003. New specimens of xenacanth and hybodont sharks from the Lower Permian of Southwestern Oklahoma. - Oklahoma Geology Notes 63 (4): 136-147. 